\title{
Portfolio Selection and Performance Evaluation Through Benjamin Graham's Value Investing
}

\author{
Vinay K. Srivastava \\ Associate Professor \\ Institute of Technology \& Science, Ghaziabad, India \\ E-mail: vks.ismdr@gmail.com \\ Nitin Kulshrestha \\ Research Scholar \\ Alabbar School of Management \\ Raffles University, Neemrana, Raj., India \\ E-mail: mymagictime@gmail.com
}

Received: June 03, 2020

doi: I0.4628I/ijfb.v4i2.688
Accepted: June 30, 2020

Online Published: August 03, 2020

URL: https://doi.org/I0.4628I/ijfb.v4i2.688

\begin{abstract}
Purpose: The objective of this study is to validate the value investing concerning filtering valued stock in the Indian stock market (Nifty 50) \& United States (Dow Jones) during the period 2014 -20.

Design /Methodologies/Approach: We have selected the data of the National Stock Exchange and Dow Jones to apply the value investing technique for choosing the stocks and building a significant portfolio. Further, we compare the mean returns of B \& H passive strategy. The empirical analysis includes the selected portfolio from Jan 2014 to May 2020.

Results \& Practical Implication: The mean return of portfolio selected by Value investing outperform as comparative to passive strategy, i.e. Buy \& Hold strategy. The successful application of value investing will encourage the practitioners $\&$ academicians of financial markets to research \& explore further uses \& practical impact of the present study.
\end{abstract}

Keywords: Value Investing, The Margin of Safety, Fundamental Analysis, Nifty Index, Portfolio, Dow Jones.

\section{JEL Classification Codes: F37.}

\section{Introduction}

Benjamin Graham says that "stock is not just a ticker symbol or an electronic blip; it is an ownership interest in an actual business, with an underlying value that does not depend on its share price". The stock market is like a pendulum that always swings between unsustainable optimism \& unjustified pessimism.

The negative effect of the crash of 1929 influenced Graham and Dodd (1934) to develop a system or framework to analyze stock market fundamentals. They proposed a "Value investing technique to identify undervalued shares in the financial universe". They said that investors need to invest with a significant gap between the current market price $\&$ margin of safety. Furthermore, the companies having low prices relative to earnings, dividends $\&$ book assets are considered as value strategy (Lakonishok, Shleifer, \& Vishny, 1994). The value analysis identifies a traditional fundamental analysis approach in selecting good stocks for an investment portfolio (Ahmed, 1997). The value strategy identifies winner stocks \& loser's stocks in the financial market with the minimum possible risk \& outperforms the market as a whole.

In the investment arena, one of the most respectful \& critical theories is the "Efficient Market Hypothesis" proposed by Fama (1970). He suggests that an investor cannot "beat the market" in any circumstances because stock market "prices" are always efficient in all conditions. The market is fully expressing all the information concerning the current price, known as efficient markets. He advocates three forms of the market (Cuthbertson \& Nitzsche, 2005; Jensen, 1978; Mandelker, Clarke, \& Jandik, 200I) i) Weak form of market ii) Semi strong form of market iii) Strong form of market. The EMH states that the current stock price reflects all the available information about the value of firms, \& there is no way to earn an excess return by using public information or private information (Mandelker et al., 200I). Hence, evaluating the stocks through value investing techniques developed by Benjamin Graham may light our path in the price discovery \& exploit the inefficiency in the market.

Many researchers had to examine the relevance of Value investing but they mainly focus on mature financial markets, like Oppenheimer and Schlarbaum (198I), Lauterbach and Vu (1993), Quah (2008), Xiao and Arnold (2008), Bildersee, 
Cheh, and Zutshi (1993), Klerck and Maritz (1997), Oppenheimer (1984, 1986), Vu (I988), Balik and Mehran (2008), Chang (20II), Singh and Kaur (20I4), and Vanstone, Finnie, and Tan (2004).

The present study is an attempt to build a portfolio based on the Value investing strategy; we concentrate on Nifty50 \& Dow Jones during the sample time frame of 2014-2020. This paper consists of five-part:

- Theoretical concept building

- Literature review\& objectives

- Description of research methods

- Empirical Results \& Conclusion

- Conclusion \& Future Dimensions

\section{I.I Theoretical Concept Building - Benjamin Graham Stock Selection Criteria}

The concept of margin of safety is the core principle of value investing; MOS means the difference between current market price \& intrinsic value. Graham (1949) accumulated six decades of extraordinary intellect with profound common sense \& vast experience into the following factors that would help investors to filtered value stocks from the financial universe. These are the following factors we need to understand value investing.

- Earning to price yield

- Price Earnings Ratio

- Dividend yield

- Tangible book value

- Net Current Assets Value

- Total debts

- Current ratio

- Earnings growth

- Stability of growth

Value investing utilizing a traditional fundamental approach in selecting stocks for investment portfolios (Ahmed, 1997). The origin of Value investing started dated back 1930, the Columbia Business School professor Benjamin Graham and Dodd (1934) had created significant support for stock market investment. In 1934, both developed value investing by using the sound principles of company fundamentals. For the stock selection, we use this formula developed by Benjamin Graham for this study.

\section{Intrinsic Valuation of Stocks -Benjamin Graham}

The original formula shared by Graham in 1962 was

$\mathrm{V}=\operatorname{EPS}(8.5+2 \mathrm{~g})$

Here,

$\mathrm{V}=$ Intrinsic Value of stock

$\mathrm{EPS}=$ trailing twelve months' earnings per share

$8.5=\mathrm{PE}$ of a stock at $\mathrm{O} \%$ growth rate

$\mathrm{g}=$ Growth rate of the company

Later, it was revised in 1974 revised edition of "The Intelligent Investor" as

$\mathrm{V}=\left[\mathrm{EPS}^{\star}(8.5+2 \mathrm{~g}) * 4.4\right] / \mathrm{Y}$

We need to update formulas according to the current financial state of a particular country. In our case, we need to update according to the financials of India \& the United States.

\section{Review of Literature}

Palazzo, Savoia, Securato, and Bergmann (2018) confirm the validity of the Value investing technique at the Brazilian stock exchange by getting higher adjusted returns during the sample time frame, i.e. May 2005- April 2015. Over time many individuals develop the investment ideologies to reduce the risk \& maximize the profits, those ideologies termed as investment philosophies (Damodaran, 2006).

Rea (I977) advised that the most essential filters were those related to the earnings offered by stocks like PE ratio. There is no documented study by Graham that would have proven that after using these criteria alone would generate a portfolio with significant performance. Conversely, Oppenheimer (1984) states that value investment portfolios obtained above-market performance between 1974-198I. Further, after using the same criteria, Klerck and Martiz (1997) also get returns above average. Also, we can have club Graham's model $\&$ other stock selection rules to build a neural network, $\&$ able to manage significant returns (Vanstone et al., 2004; Quah, 2008). Nevertheless, Xiao and Arnold (2008) examine the applicability of NCAV to market value strategy on the London stock exchange during the sample time frame I98I-2005 \& they had significantly positive returns over five years holding period.

It is a very challenging job to find stocks that fulfill all the criteria suggested by Graham (Artuso \& Chaves Neto, 20I0). Almeida, Oliveira, Botrel, and Martins (20II) and Testa (20II) also obtained results that give positivity, significance, \& validity of the value investing method. There is the number of researchers who had to examine the relevance of Value investing, but they mainly focus on mature financial markets, like Oppenheimer and Schlarbaum (I98I), Xiao and Arnold 
(2008), Oppenheimer (1984, 1986), Vanstone et al. (2004), Vu (1988), Lauterbach and Vu (1993), Bildersee et al. (1993), Klerck and Maritz (1997), Quah (2008), Balik \& Mehran (2008), Chang (20I I), and Singh and Kaur (20I4).

This research paper examines the value investing technique in the developed financial markets (United States) \& developing financial markets (India). The principal objective of the present studies as follows:

- Develop a portfolio based on the value investing technique by focusing on Nifty \& Dow Jones.

- Compare the returns accumulated by Value investing (Fundamental analysis) \& Passive investment strategy (B \& H strategy).

\section{Hypothesis}

- (HoI) The mean return of value investing is equal to B \& H strategy in the Indian stock market (Nifty).

- $\quad\left(\mathrm{H}_{02}\right)$ The mean return of value investing is equal to B \& H strategy in International Stock market (Dow Jones)

\section{Description of Research Methods}

We select the stocks based on value investing developed by Graham (1949) in the financial universe of Nifty \& Dow Jones. The origin of Value investing started dated back to 1930 when the crashes of 1929 prompted the Columbia Business School professor Benjamin Graham \& Dodd to create significant support for stock market investment. In 1934, both developed value investing by using sound principles of company fundamentals. For the stock selection, we use this formula developed by Benjamin Graham for this study.

\section{Intrinsic Valuation of Stocks -Benjamin Graham}

The original formula shared by Graham in 1962 was

$\mathrm{V}=\mathrm{EPS}(8.5+2 \mathrm{~g})$

Here,

$\mathrm{V}=$ Intrinsic Value of stock

EPS $=$ Trailing twelve months' earnings per share

$8.5=\mathrm{PE}$ of a stock at $0 \%$ growth rate

$\mathrm{g}=$ Growth rate of the company

Later, it was revised in 1974 revised edition of "The Intelligent Investor" as $\mathrm{V}=\left[\mathrm{EPS}^{*}(8.5+2 \mathrm{~g}) * 4.4\right] / \mathrm{Y}$

\section{For the United States}

In this formula, the United States' risk-free return was $4.4 \%$ \& Y represents AAA corporate bond yield. Graham includes Y because of the minimum required rate of return for investing in a stock. As we know, bond rates affect the valuation, lower the yield higher the price. Since all intrinsic value calculations are based upon opportunity cost relative to the risk-free interest, so we need to modify the formula for the Indian market \& US market.

\section{For Indian Market}

Intrinsic value $=\left[\mathrm{EPS}^{\star}(8.5+2 \mathrm{G}) * \mathrm{FD}\right.$ rate $] / \mathrm{Y}$

Here, the fixed deposit rate (risk-free rate) is $8.5 \&$ the Nifty AAA Corporate bond is 8.3 .

After selecting the stocks, we compare the value investing strategy with a passive strategy $(\mathrm{B} \& \mathrm{H})$ in terms of mean returns significance. During the sample period (Jan 2014 to May 2020), we buy all the suggestive stocks at the initial out of sample period. We kept stock throughout the whole period. The passive strategy ignores risk management, timing \& other active strategy variables. This strategy we use as a benchmark is in line with prior literature (Dryden, 1970; Fama \& Blume, I966; Vanstone et al., 2004; Thawornwong, Enke, \& Dagli, 2003).

\section{Empirical Results}

Table. I The Valued Stock Selected -Nifty (India)

\begin{tabular}{lllllllll}
\hline $\begin{array}{l}\text { Sr. } \\
\text { No. }\end{array}$ & Company & $\begin{array}{l}\text { Nifty } \\
\text { Weighted }\end{array}$ & $\begin{array}{l}\text { EPS } \\
\text { Ratio }\end{array}$ & $\begin{array}{l}\text { EPS } \\
\text { Growth } \\
\text { Rate }\end{array}$ & $\begin{array}{l}\text { Adj. Closing } \\
\text { Price as on } \\
\text { JAN 20I4 }\end{array}$ & $\begin{array}{l}\text { Intrinsic } \\
\text { Value }\end{array}$ & MOS \% & Recommendation \\
\hline I & Axis Bank & 3.35 & 26.86 & I5.33 & 207 & 866.34 & 318.52 & BUY \\
\hline 2 & HDFC Bank & I0.56 & I8.22 & 26.17 & 293 & 891.06 & 204.12 & BUY \\
\hline 3 & HDFC Bank & 8.07 & 34.89 & I8.62 & 749 & I301.67 & 73.79 & BUY \\
\hline 4 & KOTAK Bank & 4.49 & I6 & 9.14 & 326 & 543.75 & 66.80 & BUY \\
\hline 5 & ICICI Bank & 6.95 & I7.38 & I4.7 & I38 & 363.92 & I63.7I & BUY \\
\hline 6 & ITC & 4.14 & 7.45 & I9 & I89 & 282.29 & 49.36 & BUY \\
\hline 7 & TCS & 5.36 & 48.85 & II.3I & 931 & I273.94 & 36.84 & BUY \\
\hline 8 & INFY & 6.56 & 23.29 & I3.I7 & 294 & 673.92 & I29.22 & BUY \\
\hline 9 & LT & 3.2 & 35.26 & I0.39 & 578 & 869.70 & 50.47 & BUY \\
\hline I0 & RIL & I0.06 & 76.55 & 7.59 & 384 & I558.88 & 305.96 & BUY \\
\hline & & & Source: Computed & & &
\end{tabular}


Table. 2 The Valued Stock Selected - Dow Jones (United States)

\begin{tabular}{|c|c|c|c|c|c|c|c|c|}
\hline $\begin{array}{l}\text { Sr. } \\
\text { No. }\end{array}$ & Company & $\begin{array}{l}\text { Dow } \\
\text { Jones } \\
\text { Weighted }\end{array}$ & $\begin{array}{l}\text { EPS } \\
\text { Ratio }\end{array}$ & $\begin{array}{l}\text { EPS } \\
\text { Growth } \\
\text { Rate }\end{array}$ & $\begin{array}{l}\text { Adj. } \\
\text { Closing } \\
\text { Price as on } \\
\text { JAN 20I4 }\end{array}$ & $\begin{array}{l}\text { Intrinsic } \\
\text { Value }\end{array}$ & $\begin{array}{l}\text { MOS } \\
\%\end{array}$ & Recommendation \\
\hline $\mathrm{I}$ & Apple Inc. & 8.59 & 12.66 & 17.64 & 64.03 & 443.58 & 592.77 & BUY \\
\hline 2 & Microsoft Cor. & 4.95 & 2.69 & 35 & 32.88 & I64.46 & 400.17 & BUY \\
\hline 3 & IBM Cor. & 3.37 & $\mathrm{I} 4.94$ & 8.1 & 135 & 309.20 & 129.04 & BUY \\
\hline 4 & Home Depot & $6.7 \mathrm{I}$ & 3.65 & 21.2 & 66.35 & $\mathrm{I} 47.42$ & I22.19 & BUY \\
\hline 5 & McDonald's & 5.03 & 28.1 & 3.95 & 77.57 & 406.25 & $423.7 \mathrm{I}$ & BUY \\
\hline 6 & The Goldman Sachs & $5.3 \mathrm{I}$ & I5.25 & 7.1 & $\mathrm{I} 48$ & 292.69 & 97.76 & BUY \\
\hline 7 & Visa Inc. $(\mathrm{V})$ & 5.28 & 1.77 & $4 \mathrm{I}$ & $5 \mathrm{I}$ & I6I & 215.69 & BUY \\
\hline 8 & 3M Company & 4.23 & 6.72 & 10.9 & 107.3 & 204.07 & 90.17 & BUY \\
\hline 9 & Johnson \& Johnson & 4.02 & $4.8 \mathrm{I}$ & $3 I$ & 74.05 & 339.86 & 358.96 & BUY \\
\hline 10 & UnitedHealth Group & 8.24 & 5.44 & 6.1 & 65.45 & I I2.86 & 72.44 & BUY \\
\hline
\end{tabular}

After applying the value investing strategy $\&$ index weighted, we finalize these ten stocks from Nifty $\&$ Dow Jones each (table I \& 2). All these stocks have current market prices is that they are undervalued as compared to Intrinsic Value. All of the shares have a reasonably outstanding margin of safety. Buy recommendation automate as $\&$ when the current price is undervalued. Now, we choose the highest market price during the sample time frame as a closing price, \& compare it with the passive investment strategy ( $B \mathrm{H}$ ). The margin of safety is the difference between market price $\&$ intrinsic value, it is crucial in case of any drawdown in the amount of investment.

Table 3. Comparative Analysis of Mean returns of (FA) \& (B \& H)

\begin{tabular}{|c|c|c|c|}
\hline Index \& Country & NAME & B \& H (Passive Investment) ROI & FA-Value Investment ROI \\
\hline \multirow[t]{10}{*}{ NIFTY(India) } & Axis Bank & 7.66 & 44.67 \\
\hline & HDFC Bank & 19.36 & 25.36 \\
\hline & HDFC Bank & $\mathrm{I} 2.73$ & 5.75 \\
\hline & ICICI Bank & 9.97 & 45.60 \\
\hline & KOTAK Bank & 22.87 & 16.47 \\
\hline & ITC. & -0.74 & 12.13 \\
\hline & TCS & 9.99 & 21.94 \\
\hline & INFY & 7.37 & 28.57 \\
\hline & LT & 5.56 & II.02 \\
\hline & Reliance & 22.38 & 32.85 \\
\hline \multirow{10}{*}{$\begin{array}{l}\text { Dow Jones } \\
\text { (United States) }\end{array}$} & Apple Inc. & 25.4 & 64.15 \\
\hline & Microsoft Cor. & 28.75 & 30.47 \\
\hline & IBM Cor. & -5.24 & 5.28 \\
\hline & The Home Depot & 19.33 & 43.72 \\
\hline & McDonald's & II.76 & 28.45 \\
\hline & The Goldman Sachs & 3.19 & 12.47 \\
\hline & Visa Inc. & 22.12 & 39.12 \\
\hline & 3M Company & 3 & 21.60 \\
\hline & Johnson \& Johnson & 7.63 & I6.6I \\
\hline & United Health Group Inc. & $24.8 \mathrm{I}$ & 49.02 \\
\hline
\end{tabular}

Table 4. Total Portfolio Performances -Nifty \& Dow Jones

\begin{tabular}{llllll}
\hline Index & Total Portfolio(Investment Model) & Mean Return & S.D & $\begin{array}{l}\text { Risk } \\
\text { Premium }\end{array}$ & Sharpe Ratio \\
\hline \multirow{2}{*}{ Nifty } & FA (Intrinsic Value) & 24.44 & I3.7 & I7.94 & I.3I \\
\cline { 2 - 6 } & B \& H (Passive Strategy) & I I.72 & 7.7 & 5.22 & 0.68 \\
\hline \multirow{2}{*}{ Dow Jones } & FA (Intrinsic Value) & 31.09 & I8.1 & 27.09 & I.72 \\
\cline { 2 - 7 } & B \& H (Passive Strategy) & I4.08 & I I.6 & I0.08 & I.2I \\
\hline
\end{tabular}


Table 3 has shown the mean returns of the B \& H strategy \& Value investing strategy. All the stocks of Dow Jones \& Nifty outperform the B \& H strategy. As per Table no. 4, the overall portfolio performance of Nifty \& Dow Jones is outstanding. Mean returns of intrinsic value, Nifty selected stocks are 24.44 and B \& H strategy is II.72, on the other hand, portfolio performance of Nifty \& Dow Jones, the mean returns based on the intrinsic value of Dow Jones selected stocks is $3 \mathrm{I} .09 \& \mathrm{~B} \& \mathrm{H}$ strategy is I4.08. Both the index based on value investing selected portfolio outperform the B \& $\mathrm{H}$ strategy. The Sharpe ratio signifies risk premium per unit of risk, here also Nifty \& Dow outperforms by getting I.3I \& I.7I respectively. Higher the Sharpe ratio better the performance \& greater the profits for taking additional risk.

\section{I Statistical Analysis}

One-Sample Test- Nifty

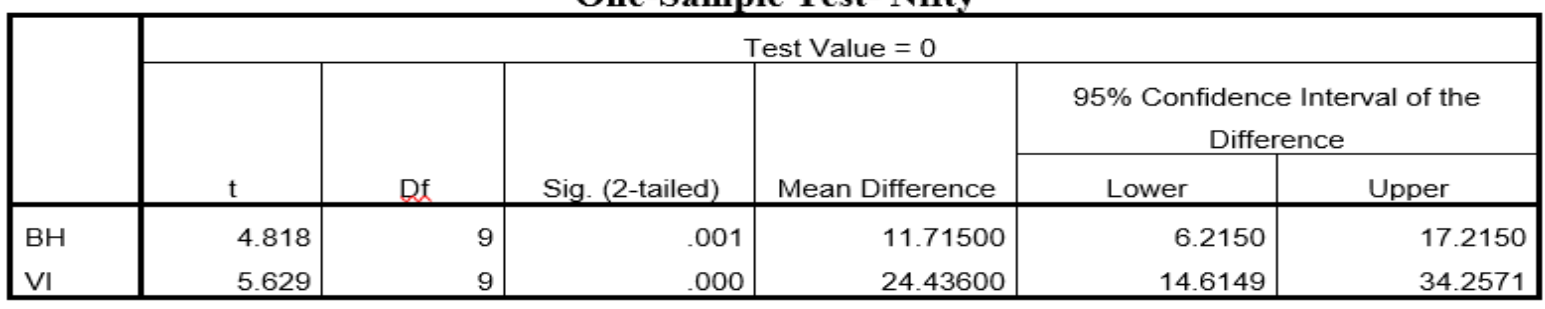

Source: Computed

The mean return of B \& H strategy (I I.7) \& intrinsic value (24.43) is statistically significant at the .05 sig. level, since p-value is .00I ( $\mathrm{B} \& \mathrm{H}) \& .000$ (intrinsic value). ( $\mathrm{HoI}_{\mathrm{I}}$ ) The mean return of value investing is more than as compared to B \& $\mathrm{H}$ strategy in the Indian stock market (Nifty), the null hypothesis can be rejected concerning the following results.

One-Sample Test- Dow Jones

\begin{tabular}{|c|c|c|c|c|c|c|}
\hline & \multicolumn{6}{|c|}{ Test Value $=0$} \\
\hline & \multirow[b]{2}{*}{$\mathrm{t}$} & \multirow[b]{2}{*}{$\mathrm{Df}$} & \multirow[b]{2}{*}{ Sig. (2-tailed) } & \multirow[b]{2}{*}{ Mean Difference } & \multicolumn{2}{|c|}{$\begin{array}{l}\text { 95\% Confidence Interval of the } \\
\text { Difference }\end{array}$} \\
\hline & & & & & Lower & Upper \\
\hline $\mathrm{BH}$ & 3.835 & 9 & .004 & 14.07500 & 5.7726 & 22.3774 \\
\hline VI & 5.423 & 9 & .000 & 31.08900 & 18.1193 & 44.0587 \\
\hline
\end{tabular}

Source: Computed

The mean return of B \& H strategy (I4.07) \& intrinsic value (3I.08) is statistically significant at the .05 sig. level, since $\mathrm{p}$-value is .00I ( $\mathrm{B} \& \mathrm{H}) \& .000$ (intrinsic value). ( $\left.\mathrm{H}_{02}\right)$ The mean return of value investing is more than $\mathrm{B} \& \mathrm{H}$ strategy in International Stock market (Dow Jones)

\section{Conclusion \& Future Dimensions}

Benjamin Graham's value investing technique provides significant results in both Nifty \& Dow Jones. Since (HoI), The mean return of value investing is equal to B \& H strategy in Indian stock market (Nifty), but our results suggest that the mean returns value investing outperforms the $\mathrm{B} \& \mathrm{H}$ strategy in Indian stock market, also, ( $\left.\mathrm{H}_{02}\right)$ The mean return of value investing is equal to B \& $\mathrm{H}$ strategy in International Stock market (Dow Jones); nevertheless, the mean returns value investing outperforms the B \& $\mathrm{H}$ strategy in International stock market statistically \& practically significant results have been found.

Future research could follow the synchronization of different variables with Graham stock selection technique like behavioral finance, ANN, techno-fundamental analysis, expert system \& other macro-economic/microeconomic variables may enhance the results.

\section{References}

Ahmed, I. (1997). Value investing on the Bombay (Mumbai) stock exchange-post sell off 1997. Available at SSRN I307867.

Almeida, V. G., Oliveira, P. H., Botrel, P. C., \& Martins, M. (20II). Teste da aplicação de critérios de análise fundamentalista às ações negociadas na Bovespa: 1997-20II. Anais do XIV SemeAD - Seminários em Administração, São Paulo, SP, Brazil. Retrieved from http://www.ead.fea.usp.br/semead/I4semead/ resultado/trabalhosPDF/I066.pdf

Artuso, A. R., \& Chaves Neto, A. (2010). O uso de quartis para a aplicação dos filtros de Graham na Bovespa (I9982009). Revista Contabilidade \& Finanças, 2I(52), I-20. 
Balik, R., \& Mehran, J. (2008). Benjamin Graham revisited. available at: www. academy financial. org/09Conference/O9Proceedings/(5D)\% 20Balik,\% 20Mehran. pdf (accessed February 25, 20I0).

Bildersee, J. S., Cheh, J. J., \& Zutshi, A. (I993). The performance of Japanese common stocks in relation to their net current asset values. Japan and the World Economy, 5(3), 197-2I5.

Chang, D. (20II). Testing some of Benjamin Graham's stock selection criteria: A case of the FTSE Bursa Malaysia EMAS Index from Year 2000 to 2009. Jurnal Manajemen Dan Kewirausahaan, I3(2), 99-106.

Cuthbertson, K., \& Nitzsche, D. (2005). Quantitative financial economics: stocks, bonds, and foreign exchange. John Wiley \& Sons.

Damodaran, A. (2006). Filosofias de investimento. Qualitymark Editora Ltda.

Dryden, M. M. (1970). A Statistical Study of U.K. Share Prices. Scottish Journal of Political Economy, I7(3), 369-389.

Fama, E. F. (1970). Efficient capital markets: A review of theory and empirical work. The journal of Finance, 25(2), $383-$ 417.

Fama, E. F., \& Blume, M. E. (I966). Filter rules and stock market trading. The Journal of Business, 39(I), 226-24I.

Graham, B. (1949). The Intelligent Investor, Harper Collins Publishers, New York, NY.

Graham, B., \& Dodd, D. L. F. (1934). Security Analysis. New York, NY: McGraw-Hill Education.

Jensen, M. C. (1978). Some anomalous evidence regarding market efficiency. Journal of financial economics, 6(2/3), 95IOI.

Klerck, W. G., \& Maritz, A. C. (I997). A test of Graham's stock selection criteria on industrial shares traded on the JSE. Investment Analysts Joumal, 26(45), 25-33.

Lakonishok, J., Shleifer, A., \& Vishny, R. W. (1994). Contrarian investment, extrapolation, and risk. The journal of finance, 49(5), I54I-I578.

Lauterbach, B., \& Vu, J. D. (I993). Ben Graham's net current asset value rule revisited: the size-adjusted returns. Quarterly Journal of Business and Economics, 82-108.

Mandelker, G., Clarke, J., \& Jandik, T. (200I). Expert Financial Planning: Investment Strategies from Industry Leaders, Chapter: The Efficient Markets Hypothesis.

Oppenheimer, H. R. (1984). A test of Benjamin stock selection criteria, Financial Analyst Journal, 40, 68-74.

Oppenheimer, H. R. (1986). Ben Graham’s Net Current Asset Values: A Performance Update. Financial Analysts Journal, $42(6), 40-47$.

Oppenheimer, H. R., \& Schlarbaum, G. G. (I98I). Investing with Ben Graham: an ex-ante test of the efficient markets hypothesis. Journal of Financial and Quantitative Analysis, 34I-360.

Palazzo, V., Savoia, J. R., Securato, J. R., \& Bergmann, D. R. (2018). Análise de carteiras de valor no mercado brasileiro. Revista Contabilidade \& Finanças, $29(78), 452-468$.

Quah, T. S. (2008). DJIA stock selection assisted by the neural network. Expert Systems with Applications, 35(I-2), 5058.

Rea, J. B. (1977). Remembering Benjamin Graham-Teacher and Friend. The Journal of Portfolio Management, 3(4), 66-72.

Singh, J., \& Kaur, K. (2014). Testing Ben Graham's stock selection criteria in the Indian stock market. Management and Labour Studies, 39(I), 43-62.

Testa, C. H. R. (20II). Aplicação da estratégia de investimento de Graham à BM\&FBovespa para o pequeno investidor. SemeAD-Seminários em Administração, I4, I-I2.

Thawornwong, S., Enke, D., \& Dagli, C. (2003). Neural networks as a decision-maker for stock trading: a technical analysis approach. International Journal of Smart Engineering System Design, 5(4), 313-325.

Vanstone, B., Finnie, G., \& Tan, C. (2004). Applying fundamental analysis \& neural network in the Australian stock market.

Vu, J. D. (1988). An Empirical analysis of Ben Graham's net current asset value rule. Financial Review, 23(2), 215-225.

Xiao, Y., \& Arnold, G. C. (2008). Testing Benjamin Graham's net current asset value strategy in London. The Journal of Investing, I7(4), I I-I9.

\section{Copyrights}

Copyright for this article is retained by the author(s), with first publication rights granted to the journal. This is an openaccess article distributed under the terms and conditions of the Creative Commons Attribution license (http://creativecommons.org/licenses/by/4.0/). 